\title{
In Vitro Stability of Phytase from Recombinant Bacteria E. Coli BL21 (DE3) EAS1-AMP
}

\author{
Adi Magna P. Nuhriawangsa ${ }^{1}$, Sajidan ${ }^{2}$, Zaenal Bachruddin ${ }^{3}$ and Ali Wibowo ${ }^{3}$ \\ ${ }^{1}$ Deparment of Animal Science, Faculty of Agriculture, Sebelas Maret University \\ Jl. Ir. Sutami No.36A Surakarta 57126, E-mail: magnapatriadi@yahoo.com \\ ${ }^{2}$ Department of Biology, Faculty of Teaching and Education, Sebelas Maret University \\ Jl. Ir. Sutami 36A Surakarta, 57126 \\ ${ }^{3}$ Departement of Biochemistry and Nutrition, Faculty of Animal Science, Gadjah Mada University, \\ Jl. Fauna 3, Yogyakarta 55281
}

\begin{abstract}
The objective of the research was to inquire the $\mathrm{Km}, \mathrm{Vm}$, activity, intracellular phytase stability exposed to $\mathrm{pH}$ variation, temperature variation and protease (pepsin and pancreas) in vitro. The phytase was produced from recombinant bacteria E. coli BL21(DE3) EAS1-AMP using $1.5 \mathrm{mM}$ IPTG as inducer. Intracellular enzyme was extracted via freeze shock and centrifugation. Pure enzyme was acquired through NI-NTA agarose column. The enzyme was then tested for $\mathrm{Km}, \mathrm{Vm}$, phytase activity and stability against $\mathrm{pH}$, temperature and protease. Treatment levels for stability against protease were $\mathrm{P}_{0}$ : without protease, $\mathrm{P}_{1}$ : addition of pepsin, $\mathrm{P} 2$ : addition of pepsin and pancreas, and the data were statistically analyzed using analysis of variance of one-way Completely Randomized Design. Crude intracellular phytase had Vm 6.39 vM/sec, Km 34.82 vM, and 277 units activity. Intracellular phytas was stable at pH $4-6$ and $0-55^{\circ} \mathrm{C}$. Protease level influenced the activity of intracellular phytase $(\mathrm{P}<0.05)$. Intracellular phytase was stable against pepsin but not pancreas.
\end{abstract}

Keywords: Km, Vm, activity, intracellular phytase, $\mathrm{pH}$, temperature, protease

\section{Stabilitas Fitase Secara In Vitro dari Bakteri Rekombinan E. Coli BL21(DE3) EAS1-AMP}

\begin{abstract}
ABSTRAK
Penelitian bertujuan untuk mengetahui $\mathrm{Km}$, Vm, aktivitas, stabilitas fitase intraseluler terhadap $\mathrm{pH}$, suhu dan protease (pepsin dan pankreas) secara in vitro. Fitase diproduksi dari bakteri rekombinan E. coli BL21(DE3) EAS1-AMP dengan menggunakan induktor 1,5 mM IPTG. Ekstraksi enzim intraseluller menggunakan cekaman beku dan sentrifugasi. Enzim murni diperoleh dengan menggunakan kolom NI-NTA Agarosa. Enzim kemudian diuji untuk Km, Vm, aktivitas, serta stabilitas terhadap $\mathrm{pH}$, suhu dan protease. Untuk stabilitas terhadap protease, level perlakuan adalah $P_{0}$ : tanpa protease, $P_{1}$ : penambahan pepsin, $P_{2}$ : penambahan pepsin dan pancreas kemudian data dianalisis statistik menggunakan Rancangan Acak Lengkap Pola Searah. Fitase kasar intraseluller mempunyai nilai $\mathrm{Vm}$ 2,41 vM/detik, Km 15,91 vM dan aktivitas 246 unit. Fitase murni intrseluller mempunyai nilai Vm 6,39 vM/detik, Km 34,82 vM dan aktivitas 277 unit. Fitase intraseluller stabil pada pH 4 sampai 6 dan suhu 0 sampai $55^{\circ} \mathrm{C}$. Level protease berpengaruh terhadap aktivitas fitase intraseluller $(P<0,05)$. Fitase intraseluller stabil terhadap pepsin, tetapi tidak stabil terhadap pankreas.
\end{abstract}

Kata kunci: Km, Vm, aktivitas, fitase intraselluler, $p H$, temperatur, pepsin, pankreas 


\section{INTRODUCTION}

Phytase enzyme is absent in the digestive tract of non-ruminant animals since the digestive tract of non ruminant do not produce this enzyme. Therefore, phytates found in seed cannot be digested due to its strong chelating character and discarded to the environment with feces (Shint et al., 2001) in the form of phytate bound (Jendza et al., 2006). It is simultaneously excreted by poultry to the environment which can cause serious negative effects (Saryska et al., 2005). This waste is a pollutant to the environment (Daniel et al., 1998).

Phytase is an enzyme, which is also a protein, thus can be easily degraded by environmental conditions (Anselme, 2006). Some requirements which must be observed in the practical application of enzyme in poultry are that the enzyme must be able to withstand heat, acidic $\mathrm{pH}$, and protease activity (Abondano, 2009).

Pure intracellular phytase from recombinant bacteria $E$. coli BL21(DE3) EAS1-AMP had been produced and characterized (Nuhriawangsa et al., 2010). However, the stability of the enzyme in the digestive tract of non ruminant animal is not yet known, thus the research was aimed to determine the $\mathrm{Vm}$, Km, activity and intracellular phytase stability in vitro.

\section{MATERIALS AND METHOD}

Materials used in this experiment were recombinant bacteria $E$. coli BL21(DE3) EAS1-AMP, crude intracellular phytase for $\mathrm{pH}$ and temperature stability trial, pure intracellular phytase for protease level trial, Luria Bertany (LB) medium containing Amp $25 \mathrm{vg} / \mathrm{ml}$, STOP solution, $1.5 \mathrm{mM}$ IPTG, NINTA Agarose, Na-Phytate, rice brain, distilled water, $\mathrm{HCl}$, pepsin (Sigma, catalog P-7012), $\mathrm{NaHCO}_{3}$, pancreas (Sigma, catalog P-3292), dialysis tube (Sigma, catalog D-9652-100FT), parafilm, $\mathrm{NaCl}$, EDTA, sodium succinate, and sulphuric acid.

\section{Measurement of $\mathrm{Km}, \mathrm{Vm}$, and Phytase Activity}

$\mathrm{Km}$ and $\mathrm{Vm}$ values were determined following according to Robyt and White (1997) by comparing products before and after hydrolysis. Phytase activity value in unit enzymes, was defined as portion of phytase that can convert 1 umol orthophosphate from phytate per minute at $\mathrm{pH} 5.5$ and $37^{\circ} \mathrm{C}$ (Zyle et al., 1995). In this research $\mathrm{pH} 5$ and $45^{\circ} \mathrm{C}$, the optimum intracellular phytase temperature and $\mathrm{pH}$ was used (Nuhriawangsa et al., 2009).

\section{Measurement of Phytase Relative Activity}

Phytase activity was measured following the method of Sajidan (2002): $50 \mu$ l enzyme, $150 \mu$ l substrate $(0.4 \%$ Na-phytate in $100 \mathrm{mM}$ Na-acetate) incubated at $37^{0} \mathrm{C}$ for 30 minutes. Reaction was stopped by adding $400 \mu \mathrm{l}$ STOP solution. Yellow color of phosphomolybdate was measured using spectrophotometer at $\lambda$ $415 \mathrm{~nm}$.

\section{Analysis of Phytase $\mathrm{pH}$ and Temperature Stability}

The $\mathrm{pH}$ and temperature stabilities were measured accorging to Sajidan (2002) by observing the relative activity. Temperature stability trial was done by heating the phytase at varying temperature $(0,20,37,40,45,50$, 55, 60, and $65^{\circ} \mathrm{C}$ ) for 10 minutes and followed by phytase activity trial. The $\mathrm{pH}$ stability trial was done by incubating phytase in Na-acetate buffer at varying $\mathrm{pH}(2,3,4,5$, $6,7,8)$.

\section{Analysis of Phytase Stability against Protease}

Treatment levels were as follows $\mathrm{P}_{0}$ : without protease, $\mathrm{P}_{1}$ : addition of pepsin (6000 units $/ \mathrm{ml}), \quad \mathrm{P}_{2}$ : addition of pepsin (6000 units $/ \mathrm{ml}$ ) and pancreas (3.7 $\mathrm{mg} / \mathrm{ml})$. Phytase activity was evaluated by $\mathrm{P}$ digestibility in vitro on rice brain, which was a modification of the crop, gizzard, duodenum and small 
intestine according to $\mathrm{Wu}$ et al. (2004). In vitro digestibility was observed based on the results of $P$ value trials using spectrophotometer at $\lambda 415 \mathrm{~nm}$ (Jackson, 1985). Digestibility value $P$ was calculated by observing the difference in $\mathrm{P}$ value of feed before and after in vitro analysis in dry matter condition (Tillman et al., 1986).

\section{Statistical Analysis}

Statistical analysis of $\mathrm{Km}, \mathrm{Vm}$, enzyme activity, $\mathrm{pH}$ and temperature stability was conducted using discriminative quantitative analysis by observing the mean value from relative enzyme activity. Statistical analysis of protease stability was done by using analysis of variance of one way Completely Randomized Design (Steel and Torrie, 1993). Statistical analysis was carried out using Minitab 14 program for Microsoft Office 2003.

\section{RESULTS AND DISCUSSIONS}

The Vm, Km and activity values of pure and crude intracellular phytase are shown in Table 1. Results show that $\mathrm{Vm}, \mathrm{Km}$, and activity of pure intracellular phytase were better than crude intracellular phytase. Enzymes are proteins that possess catalytic activity due to its active group. Enzymes are produced after microbial colony is planted in media followed by fermentation. Crude enzyme after fermentation was separated from the media by ultrafiltration, precipitation, extraction, and other methods. Crude enzymes were then purified until a certain level of purity (Clarkson et al., 2001). Enzyme purification can be conducted by dialysis or ion exchange chromatography (Raju et al., 2007). According to David and Thomas (1990) protein purification is carried out with the purpose of removing contaminants so that quantitatively the protein is free from contaminants. The purified product will have better $\mathrm{Vm}, \mathrm{Km}$ and enzyme activity because various inhibitors dissolved was removed from the solvent during enzyme purification.
Results of $\mathrm{pH}$ stability of intracellular phytase is shown on Figure 1. Phytase activity ranged between $\mathrm{pH} 2$ and 8. Phytase activity increased at $\mathrm{pH} \mathrm{2-4}$ and reached optimum level at $\mathrm{pH}$ 5, than decreased at $\mathrm{pH}$ 6-8. Phytase had low activity at $\mathrm{pH}$ 2, 7 and 8, but stable at $\mathrm{pH}$ 4-6. Enzyme activity was influenced by $\mathrm{pH}$ because at certain $\mathrm{pH}$ conditions the enzyme cannot be active due to denaturation or degradation (Hendrickx et al., 1998). The $\mathrm{pH}$ influenced enzyme balance condition during denaturation, whether it is reversible or irreversible. Denaturation caused structural changes in the molecular structure of the enzyme protein, thus whether it remains active or becomes inactive will depend on the type of the damage, reversible or irreversible (Zale and Klibanov, 2004).

The bound of amino acid residues on protein are dependent on the proton concentration in its molecular composition. Increasing accumulation of $\mathrm{pH}$ value caused positif or negative instability in the molecular structure of enzyme protein. Structural instability in the enzyme protein molecule caused structural changes, leading to thus decreased of the enzyme's catalytic activity (Furlan and Pant, 2008).

The $\mathrm{pH}$ of the digestive tract of chicken in crop 4.5, proventriculus 4.4, gizzard 2.6, duodenum 5.7-6.0, jejunum 5.8, ileum 6.3, colon 6.3, and ceca 5.7 (Sun, 2004). Phytase from E. coli BL21 (DE3) EAS1-AMP recombinant bacteria was stable at $\mathrm{pH}$ 4-6. Thus, this phytase active in the crop, proventriculus, gizzard, duodenum, jejunum, ileum, colon, dan ceca, but its activity in the gizzard is low.

Results of intracellular phytase stabiliy against temperature is shown in Figure 2. Increasing the temperature caused reduction in phytase activity. This reduction was apparent at temperatures of $55-66^{0} \mathrm{C}$. Phytase activity was low at $60^{\circ} \mathrm{C}$ and almost inactive at $65^{\circ} \mathrm{C}$. According to Illanes (1994), the increased of temperature resulted in the increased of vibrational energy that broke the hydrogen bounds, thus the non-polar bound did not exist. This caused structural changes in 
Table 1. The Vm (vM/sec), Km (vM) and phytase activity (Unit) of crude intracellular and pure intracellular from recombinant bacteria E. coli BL21(DE3) EAS1-AMP

\begin{tabular}{lccc}
\hline Type of Phytase & Vm & Km & Activity \\
\hline Crude intracellular & $2,41^{*}$ & $15,91^{*}$ & 246 \\
Pure intracellular & $6,39^{* *}$ & $34,82^{* *}$ & 277 \\
\hline
\end{tabular}

*Source: Nuhriawangsa (2009).

**Source: Nuhriawangsa (2010).

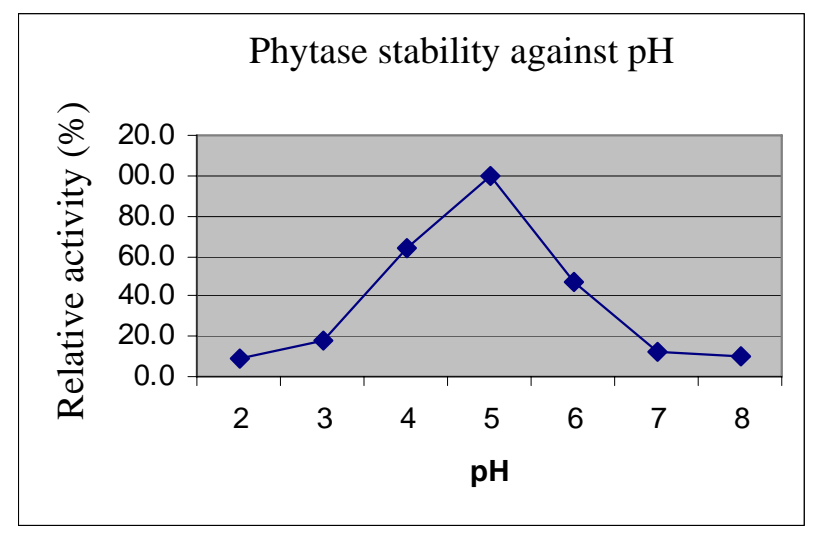

Figure 1 . Relative activity of phytase (\%) at variuos $\mathrm{pH}$ and temperature $45^{\circ} \mathrm{C}$

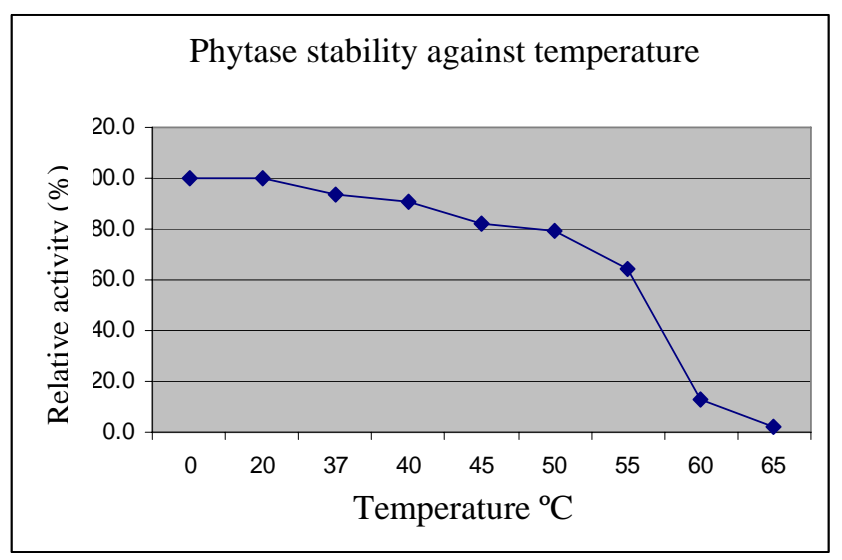

Figure 2. Relative activity of phytase (\%) at various at temperature

enzyme protein molecular structure and affected the enzyme catalytic activity.

The reduction of activity was caused by phytase denaturation due to heat exposure (Furlan and Pant, 2008). Phytase Thermomyces denaturates at $66^{\circ} \mathrm{C}$ (Berka et al., 1998). Phytase from A. ficuum at $70^{\circ} \mathrm{C}$ denaturates $25 \%$ at $\mathrm{pH} 2$ and $65 \%$ at $\mathrm{pH} 8.5$. (Shieh et al., 1969).
The normal process of pellet production for poultry feed is conducted at $85-95^{\circ} \mathrm{C}$, while the temperature of chickens' digestive tract is about $37^{0} \mathrm{C}$. Phytase from E. coli BL21 (DE3) EAS1-AMP recombinant bacteria was stable at $0-55^{\circ} \mathrm{C}$. Wang et al. (2007) found that phytase from Aspergillu fumigatus WY-2 had a low stability against high temperature, causing low activity due to enzyme damage. 
Table 2. The average of $\mathrm{P}$ (g) content in rice bran (dry matter basis) after hydrolisis without the treatments of phytase (F1), with fitase (F2), without protease protease (P1), with pepsin (P2) and with pepsin and pancreas (P3)

\begin{tabular}{|c|c|c|c|}
\hline Phytase & F1 & F2 & Average ${ }^{*}$ \\
\hline Protease & & & Average ${ }^{* *}$ \\
\hline P1 & 0.00335 & 0.00500 & $0.00418^{x}$ \\
\hline $\mathrm{P} 2$ & 0.00431 & 0.00550 & $0.00490^{\mathrm{x}, \mathrm{y}}$ \\
\hline P3 & 0.00187 & 0.00338 & $0.00263^{\mathrm{Z}}$ \\
\hline Average & $0.00318^{\mathrm{a}}$ & $0.00463^{b}$ & \\
\hline
\end{tabular}

Wyss et al. (1999) also found that phytase from Aspergillus fumagitus was stable at low temperature. These studies resulted phytase with low stability against high temperature, thus only active in the digestive tract of chickens but cannot be applied during pellet production.

In vitro result of pure intracellular phytase in rice brain against protease stability by evaluating digestibility $\mathrm{P}$ is shown in Table 2. Addition of enzyme into feed needs specific requirement since the enzyme cannot be degraded by protease in the digestion tract (Garret et al., 2004; Wang et al., 2007). This due to the fact that the production of phytase by eco-friendly bacteria and stable against proteolytic activity is needed so that it can be applied to poultry feed (Igbasan et al., 2000). Some research have been conducted to test the stability of phytase against pepsin and tripsin produced by poultry digestive organs (Wang et al., 2007; Kornegay, 2001) and pancreatin (Igbasan et al., 2000; Phillippy, 1999).

The $\mathrm{P}$ content of rice bran after in vitro hydrolysis was different $(\mathrm{P}<0.05)$ between without protease and with pepsin, without pepsin and combination of pepsin pancreas and pepsin with combination of pepsin pancreas. $P$ content increased with the addition of pepsin and decreased with the addition of pepsin-pancrease combination. According to Kornegay (2001) the decrease in enzyme activity caused by degradation by proteolytic enzyme. Reduction in enzyme activity due to proteolytic enzyme degradation is an important matter, because the activity of an enzyme against protease stability can be measured by observing the phytase activity against pepsin (Wang et al. 2007) and pancreas (Igbasan et al. 2000). Phytase from recombinant bacteria $E$. coli BL21 (DE3) EAS1-AMP was not hydrolyzed under the influence of pepsin, thus phytase activity was stable against pepsin, which was proven by increased of $\mathrm{P}$ content with the addition of pepsin compared to the absence of protease. In contrast, phytase was hydrolyzed by combination of pepsin and pancreas, which was shown by the decrease in $\mathrm{P}$ content at level of pepsin and pancreas, thus phytase was not stable against pancreas.

\section{CONCLUSION}

Crude intracellular phytase had Vm $2.41 \mathrm{vM} /$ second, Km $15.91 \mathrm{vM}$ and activity 246 units. Pure intracellular phytase had Vm 6.39 vM/second, Km $34.82 \cup \mathrm{M}$ and activity 277 units. Intracellular phytase from recombinant bacteria $E$. coli BL21 (DE3) EAS1-AMP was stable at $\mathrm{pH} 4-6,0-55^{\circ} \mathrm{C}$ and pepsin, but was not stable against pancreas.

\section{ACKNOWLEDGMENT}

We thank to Director of DP2M DIKTI Ministery of National Education, Republic of Indonesia for the research fund Hibah Bersaing 2008 Batch 2 (Contract number: 017/SP2H/PP/III/2008) and Hibah Bersaing 2010 Batch 1 (Contract number: 024/SP2H/PP/DP2M/III/2010). 


\section{REFERENCES}

Abondano, E., 2009. Enzymatic Fungtions: Protease, Amilase and Phytase. Biotechno Ebook. North Dakota State University, USA.

Anselme, P., 2006. Considerations on The Use of Microbial Phytase. CEFIC. Inorganic Feed Phosphates, Brussels.

Berka, R. M., M. W. Rey, K. M. Brown, T. Byun and A. V. Klotz, 1998. Molecular Characterization and Expression of a Phytase Genefrom the Thermophilic Fungus Thermomyces lanuginosus. J. App. Enviro. Microbiol. 64(11):4423-4427.

Clarkson, K., B. Jones, R. Batt, B. Bower, G. Chotani, and T. Becker, 2001. Enzymes: Screening, Expression, Design and Production. In: Enzyme in Farm Animal Nutrition. M. R. Bedford and G. G. Partridge, Eds. CABI Pub., U. K.

Daniel, T. C., A. N. Sharpley and J. L. Lemunyon, 1988. Agricultural phosphorus and eurotrophication: A symphosium review. J. Enviro. Quality. 27:251-157.

David, G. R. and M. L. Thomas, 1990. Determination of Purity. In: Methods in Enzymology: Guide to Protein Purification. M. P. Deutscher, Ed. Vol. 182. Academic Press, Toronto.

Furlan, S.A. and H.K. Pant, 2008. General Properties. In: Enzyme Technology. A. Pandey, C. Webb, C.R. Soccol and C. Larroche, Ed. N.K. Muraleedharan Asiatech Pub. Inc., Springer, New Delhi, India.

Garrett, J. B., K. A. Kretz, E. O’Donoghue, J. Kerovuo, W. Kim, N. R. Barton, G. P. Hazlewood, J. M. Short, D. E. Robertson and K. A. Gray, 2004. Enhancing the thermal tolerance and gastric performance of a microbial phytase for use as a phosphatemobilizing monogastric-feed supplement. J. App. Enviro. Microbiol. 70(5):3041-3046.

Hendrickx, M., L. Ludikhuyze, I. Van den Broeck and C. Weemaes, 1998. Effects of high pressure on enzymes related to food quality., J. Food Sci. \& Tech. 9(5):197-203.

Igbasan F. A., K. Manner, G. Miksch, R. Borriss, and A. Farouk, 2000. Comparative studies on the in vitro properties of phytases from various microbial origins J. Arch. Anim. Nutr. (4): 353 - 373.

Illanes, A., 1994. Biotechnology Enzyme. UVC, Valparafso, Chile.

Jackson, M.L. 1985. Soil Chemical Analysis. Prentice-Hall, Inc., Englewood Cliffs. NY.

Jendza, J. A., R. N. Dilger, J. S. Sands and O. Adeola, 2006. Efficacy and equivalency of an Escherichia coli-derived phytase for replacing inorganic phosphorus in the diets of broiler chickens and young pigs. J Anim. Sci. 84:3364-3374.

Kornegay, E.T., 2001. Digestion of Phosphorus and Other Nutrients: the Role of Phytases and Factors Influencing Their Activity. In: Enzymes in Farm Animal Nutrition. M.R. Bedford and G.G. Partridge, Eds. CAB, Blacksburg, USA.

Nuhriawangsa, A. M. P., Z. Bachruddin, Sajidan and A. Wibowo, 2009. Production and characterization of Crude Intracelluler Phytase from Recombinant Bacteria pEAS1AMP. J. Indon. Tropic. Anim. Agric. 34(4):265-271.

Nuhriawangsa, A. M. P., Z. Bachruddin, Sajidan and, A. Wibowo, 2010. Cloning Phytase Gen of Klibsiella pneumonia ASR1 into E. coli BL21(DE3) and Characterization of the Enzyme. In: Proceeding Conference on Industrial Enzyme and Biotechnology 2010: Enzyme Technology for Eco-Friedly Industry. Page: 135-143.

Phillippy, B. Q., 1999. Susceptibility of Wheat and Aspergillus niger Phytases to Inactivation by Gastrointestinal Enzymes. J. Agric. Food Chem. 47(4): 1385-1388.

Raju, K. J., U. Neogi, R. Saurnya and R. Goud, 2007. Studies on extracelluler enzyme Keratinase from Dermatophyte Microsporum gypseum. J. Biologic. Chem. 1(3):174-178.

Robyt, J. F. and B. J. White, 1997. Biochemical Tecniques Theory and Practice. Brooks/Cole Pub. Co., Monterey, California.

Sajidan, 2002. Molekulare Characterisierung einer Phytase (Myo-inositol Hexakiphosphate Hydrolase) und von Phosphatasen aus Bakterieisolaten indoneschicher Reisfelder (Klebsiella pneumoniae). Dissertation. Institut fuer Biologie. Humboldt Universitat zu Berlin. Deutschland (Germany). 
Sariyska, M.V., S.A. Gargova, L.A. Koleva, A.I. Angelov, 2005. Aspergilus niger Phytase: Purification and Characterization. J. Biotechnol. and Biotechnol. Eq. 19(3): 98105.

Shin, S., N.C. Ha, B.C. Oh, T.K. Oh and B.H. Oh, 2001. Enzyme mechanism and catalytic property of $\beta$ propeller phytase. Structure. 9:851-858.

Shieh, T. R., R. J. Wodzinski and J. H. Ware, 1969. Regulation of the Formation of Acid Phosphatases by Inorganic Phosphate in Aspergillus ficuum. J. Bcteriology. XII:11611165.

Steel, R.G.D dan J.H. Torrie, 1993. Principles and Prosedures of Statistic. $3^{\text {rd }}$ ed. B. Sumantri, Ed. P.T. Gramedia, Jakarta.

Sun, X., 2004. Broiler Performance and Intestinal Alterations when Fed Drug-free Diets. Thesis. Faculty of the Virginia Polytechnic Institute and State University, Blacksburg, Virginia.

Tillman, A.D., H. Hartadi, S. Reksohadiprodjo, S. Prawirokusumo dan S. Lebdosoekojo, 1986. Basic Animal Nutrition. Gadjah Mada University Press, Yogyakarta.

Wang Y., X. Gao, Q. Su, W. Wu, and Lijia, 2007. Cloning, Expression, and Enzyme Characterization of an Acid Heat-Stable
Phytase from Aspergillus fumigatus WY-2. J. Current Microbiol. 55(2007): 65-70.

Wu, Y. B., V. Ravidran, J. Pierce and W. H. Hendriks, 2002. Influence of three preparation in broiler diets based on wheat or corn: In vitro measurements of nutrient release. J. Poult. Sci. 3(7): 450-455.

Wyss, M., L. Pasamontes, A. Friedlein, R. Remy, M. Tessier, A. Kronenberger, A. Middendorf, M. Lehmann, L. Schnoebelen, U. Rothlisbuis, G. Wahl, F. Muller, Hans-Werner L., K. Vogel and P. G. M. Adolphus, 1999. Biophysical characterization of fungal phytases (myo-inositol hexaisphosphat phosphohydrolases): molecular size, glycosylation pattern and engeneering resistance. J. App. Enviro. Microbiol. 65(2):359-366.

Zale, E. and A. M. Klibanov. On the role of reversible denaturation (unfolding) in the irreversible thermal inactivation of enzymes. J. Biotec. Bioengineering. 25(9):2221-2230.

Zyla, K., D. R. Leudoux and T. L. Veum, 1995. Complete enzymic dephosphorylation of corn-soybean meal feed under simulated intestinal conditions of the turkey. J. Agric. Food Chem. 43:288-294. 